\title{
Análisis psicológico de los poemas de Forough Farrokhzad basados en las teorías de A. Adler y K. Horney
}

\section{Psychological Analysis of Forough Farrokhzad Poems Based on A. Adler and K. Horney Theories}

\author{
Seyedeh Kolsoom Fazeli ${ }^{1}$, Dr. Shahrokh Hekmat ${ }^{2 a}$ \\ Islamic Azad University, Arak, Iran ${ }^{1,2}$ \\ Orcid ID: https://orcid.org/0000-0002-6122-8258 ${ }^{1}$ \\ (D) Orcid ID: https://orcid.org/0000-0002-7458-1288²
}

Recibido: 09 de mayo de 2020

Aceptado:05 de octubre de 2020

\begin{abstract}
Resumen
El objetivo de este estudio fue el análisis psicológico de los poemas de Forough Farrokhzad basados en las teorías de A. Adler y K. Horney. Esta investigación se ha realizado utilizando un método descriptivo y análisis de contenido en el que trabaja el estudio de investigadores Forough Farrokhzad. Los resultados muestran que Forough Farrokhzad siempre se ha enfrentado con la censura y el pesimismo de la gente en nuestra sociedad de que nuestra cultura tradicional no pudo soportar su libertad que refleja sus emociones, pensamientos y afectos en sus poemas. Estos reflejan tanto las dificultades por las que ha pasado como también se hacen eco de sus problemas psicológicos, como la inferioridad, la sumisión, la agresión y el trastorno disociativo. De hecho, su autorrevelación, supremacía y soledad elegida por ella misma fueron un intento intencional de cubrir y sanar sus debilidades. Luego de analizar sobre Forough, se identificó que su actitud negativa hacia el mundo y su pesimismo ha creado paranoia en algunas de sus poesías. Ella era pesimista en algunos de sus poemas y veía a todos los hombres ya veces a todas las personas como su enemigo.
\end{abstract}

Palabras clave: Crítica literaria, Forough Farrokhzad, Alfred Adler, Karen Horney, complejo de Inferioridad, literatura persa, análisis literario

\section{Abstract}

The objective of this study was to psychological analysis of Forough Farrokhzad poems based on A. Adler and K. Horney theories. This research has been done using descriptive method and content analysis in which researchers' study Forough Farrokhzad works. Results show that

a Corresponding Author: e-mail: sh-hekmat@iau-arak.ac.ir 
Forough Farrokhzad has always been encountered with censorship and people's pessimism in our society that our traditional culture could not put up with her freedom that reflect her emotion, thoughts, and affections in her poems. These poems reflected both the difficulties she's been through and also echo her psychological problems including inferiority, submission, aggression, and dissociative disorder. Indeed, her self-disclosure, supremacy, and self-chosen solitude were intentional attempted to cover and healed her weaknesses. After analyzing about Forough, we identified that her negative attitude to world and pessimism has created paranoia in some of her poetry. She was a pessimist in some of her poems and saw all the men and sometimes all the people as her enemy.

Keywords: Literary criticism, Forough Farrokhzad, Alfred Adler, Karen Horney, Inferiority complex, Persian literature, literary analysis

\section{Introduction}

Psychological criticism has granted literary criticism with profundity and a kind of predicting mysterious aspect by scheming material related to individual and collective unconscious in literature (Shamisa 2009). Some critics relied on psychology in literary criticism and tried to communicate the poet's intrinsic stream and inner status (Zarinkoob, 2017). Therefore, studied the impact of society and traditions in developing such streams. Following the success of psychological investigations especially Sigmund Freud during the early twenties, his theories about unconscious self and his psychiatric method penetrated psychological criticism realm and became one of the most outstanding interpretive schools. The most popular analysis provided by Freud on structure and performance of mind was ego pattern, ego and superego. But as it was expected different psychiatric schools appeared after Freud which revolutionized the psychiatric literary criticism.

\section{Problem statement}

Among these majors, psychology as one of the human science majors was directly related to literature regarding so many aspects. According to Freud (1953), literary proses and creative artistic writing is speech; narration and phrasing interprets inner unconscious.

There were 3 deductions were coming as a result of the investigations and psychiatric criticism: one was the effort dedicated to psychological analysis of literature. Second was the fact that psychiatric criticism of literature could be defined as literature psychiatry; psychology and literature were 2 independent areas having connections as well (distinguish differentiated aspects of literature and psychology while highlighting the connections).The third type of psychiatric 
criticism was the psychological analysis in literature seen as efforts to discover psychological issues in literature (Moghadasi and Chakali, 2018).

There were various defensive mechanisms in her poetry against depression and anxiety and different types of complexes and psychic motives have been involved in her life style and development of her concepts and poetry toward excellence. Studying this creative poet through her poetry and applying her characteristics with Horney and Alfred psychological theories, one could extract the examples of humiliation complex, compensating mechanism, aggression, and psychosis (Shamloo, 2019).

\section{Basic anxiety}

\section{Theoretical schemes of the study}

According to Horney, the anxiety was the origin of the following neurosis and are closely connected to feeling hostility. Horney defined basic anxiety as solitude, misery, and feeling unprotected in a world which was dangerous and scary in essence (Shultz, 2017:171). Anxiety was not heritable but was a result of our culture and training such as hostility and enmity, feeling of inferiority and worthlessness, misery, disability, loneliness, being nervous and some other bad effects (Taheri, 2018). Horney (2014) believed a nervous person made efforts and used defensive mechanisms in order to alleviate the anxiety and its excitation but even these efforts just aggregated the issue and complicated the nervousness structure. Therefore, some needs as morbid needs were introduced. In this case, Horney has introduced 10 types of morbid needs of which are as follows:

\section{Affection and approval}

Affection and approval defined as be liked by others and attracted affection and agreement. A person with such a need was careful about what others thought and could not stand the slightest criticism or unkindness.

\section{Domineering partner}

Person was looking for a parasitic relationship with someone who accepted the responsibilities for everything. These people were terribly scared of being abandoned and staying alone ( Shakeri, 2018:92).

\section{Power}


A person of the need thought that they could achieve anything just by having the power of will.

\section{Exploitation}

Being the winner in every game and deal to be superior to others.

5. Credit

The social credit was the determining factor in self-assessment.

\section{Admiration}

In this situation the person had an exaggeration and arrogant self-image and expected to be praised and admired based on these false images.

\section{Progress or ambition}

Due to feeling basic insecurity the person leaded herself or himself towards having greater and beta progress.

\section{Self-sufficiency}

Because of so many failures in building satisfactory relations, the person was disappointed and thus avoided joining the others. Consequently, they would be isolated or elusive.

\section{Perfection}

The person was afraid of making mistakes and thus being criticized so they tried to play the role and identified the weaknesses before the others did (Shakeri, 2018:95).

10. Limiting life

To maintain the current situation and avoiding any kind of changes or hobbies. The main characteristic of this demand was being completely content.

\section{Morbid needs}

For the other hand, Horney categorized these 10 morbid needed in three groups. 1. Moving towards people. 2. Moving against people. 3. Moving to avoid people. Feeling isolated and frustrated usually displayed as basic anxiety made some people to act obsessively. They reacted to 
others by moving towards them submissively and by doing so they try to protect themselves from frustration (Horney, 1945).

- Moving towards people

The person who chose the path was not hopeful about being powerful and puissant. Therefore, they wanted to feel protected from other people who might tease them and also provided themselves with a support to accompany them in life (Taheri, 2018:67).

- Moving against people

The person who was following this method saw people as their enemy and believed they would be always ready to defend or attack. He aimed to be powerful and his motto was:" the powerful always right.” Weak people tried to achieve a social status gave them the opportunity to hide their inner weaknesses. The important sign of power to them and to society included: wealth, fame, success position or even knowledge. In this defensive technique the motto was: "if I gain power no one would bother me” (Taheri, 2018:67).

- Moving to avoid people

A person holding this view considered society as the origin of all sadness, tensions and miseries. They considered those choosing solitude as wise people. These people neither helped nor asked for help. They did not follow fame, position, and ambition. Their motto was: "contentment is what enriches a person”. Nervous people had to suspend their feelings and emotions in order to a stay independent because of the fear of dependency. In isolation technique the Motto was: "if I stay away from you, I'll be safe” (Taheri, 2018:67).

\section{The ideal self-image}

The neurosis people who were experiencing the conflict between the incompatible methods had an uncoordinated and not united character. They formed their self-image having the same goal of normal people. They wanted to unite their personality (Shultz, 2017:178). But they were doomed to failure. Because their images were not based on a realistic assessment of their weaknesses and strengths of themselves. But they were based on an illusion which was absolute unreachable perfection (Shakeri, 2018:98). According to the provided explanations, the following essay used Adler and Horney's theories as a theoretical framework and in the following sections there would be an analysis of these theories and poetic evidences of Forough Farrokhzad. 


\section{Alfred Adler and his psychological theories}

Alfred was considered to be as a pioneer of social psychology group in psychiatry, because he separated Sigmund Freud in 1911. He proposed a theory in which social interests played an important role and he was the only psychologist to establish a group of 4 participants named after him.

\section{Inferiority feeling}

One of the primary concepts presented by Adler was inferiority. He thought of inferiority feeling to be a complete concept was timing from psychological imperfections of members. However, he redeveloped the concept to be extended because he thought this feeling could be associated with some family issues. For instance, excessive care of children (spoilt children) by parents could also result in inferiority feeling in children. However, Adler did not consider this feeling of inferiority as a weakness point. He believed that it was a motivation Force for people's behavior (Taheri, 2018:67). An inferiority complex occurred of an individual fails to compensate for their usual inferiority and consequently felt frustrated.

\section{Aggressive drive}

According to Adler, aggression was the first prompt reaction to feeling inferiority. Aggressive was the dominant, governing and forms the combination of drives. Displaying of the drive was shown in different forms; such as hitting, biting, fighting and even sadism in a severe form. It was also displayed in indirect form; for instance, competitive races, religious, social, National, racist, political or even artistic conflicts. Sometimes of this drive showed itself inside; and the person displayed paradoxical forms of submission and humiliation which might result in Masochism too.

\section{Superiority striving}

The effort made to reach superiority striving could be mentioned as an action to cover feeling inferiority. This effort caused that they tried to maintain and increased their selfconfidence. Superiority striving was not only an individual but also a collective movement.

\section{Effort to reaching perfection}

Adler (1987) believed that Perfection was to complete and fulfill that people tried to reach and felt fulfilled. The excellent goal was to reach the complete perfection. Lazarsfeld (1966) also 
declared that there were times people lost confidence due to various reasons; there was a possibility people tried to make confidence for them by replacing unreal achievement instead of the reality and by doing so form an unrealistic image dreams which caused perfection.

\section{Compensation mechanism}

The factors influenced such mechanisms of compensation were as follows: memory, excitements, cognitive status of the patient and other factors. According to Adler, there were two categories of people when it came to compensation for imperfections. One group were the people who tried to conceal their imperfections not to be noticed by others (prestige oriented) and the second group were people who did not care about what other people think (lack oriented). Categories of people regarding their compensation techniques could be into the following groups (Shamloo, 2019).

- Compensation within the area: a person who tried to adapt with situation in the same area that was dealing with a problem.

- Compensation in other areas: for example, a person who tried to compensate for his educational weakness by succeeding in sports.

- Overcompensation (superiority complex): the situation in which the person overcame the problems by hard work and also tried to be in a higher and better situation in comparison to others.

According to Adler, the inferiority feeling existed within every individual, however this feeling caused neurotic symptoms in neurotic people, because they had the symptoms in their existence center.

\section{Karen Horney and his psychological theories}

Karen Horney was a German theoretician who developed a theory of personality based on social factors in which the impact of congenital factors is insignificant. Horney believed the neurosis could be prevented if there was understanding, safety, kindness, friendly relations, and affections in family (Shamloo, 2019).

Horney believed that a child's needs like health and immunity could be either fulfilled or caused disappointment by paying attention to early childhood experiences such as parents' interaction with children because lack of attention caused anxiety in children (Sholtez, 2017:322). 
It would be also affected by environmental and social factors such as domineering approach, lack of support, lack of affection and unstable behaviors. According to Horney, personality could change through life time and there was nothing of general nature in the growth of a child. There were some factors stemming from society and family which cause anxiety and insecurity in a child. The most important ones were: too much dominance, ignorance, unstable behavior, being disrespectful to a child's demands, excessive attention and affection, lack of needed warmth and friendliness, discrimination, overprotection, assigning responsibility none at all, aggression, and the violence to feel security (Taheri, 2018:67).

\section{Discussion of the theories of Adler and Horney in relation to the poems of Forough}

Paradoxical and controversial thoughts and mentality of poets was not surprising because a person could have paradoxical thoughts and the concepts of different phenomenon could change by passage of time. Alfred Adler investigated the psychic features of people by analyzing their lifestyle in his individualist psychology. The main criteria of assessment in individualist psychology was to investigate a person of psychological health was, social interest. According to the current theory, people of mental health tried for collective success while the people who lacked such health search for personal superiority. At the same time the theories of Horny could be helpful to show if the poet has chosen to be love thirsty, submissive, evasive or aggressive towards other people in order to compensate for such inferiority.

By psychological analysis of the poetry of an artist in whose art could be found paradox, various conclusions would be shown. It was possible to claim the poet has been a neurosis based on some poems and emphasized on mental health based on some others. Forough was not an exception as well. And obviously a feminine narrative could display the very profound and deep emotions within a female poet greatly. Features indicated love thirst and superiority and isolation

in Forough poetry (Horney's theory). Horney theory of inner conflict in Forough (moving towards people, moving against people, move to avoid people).

First, referring to some evidence regarding this poem should be considered: My love

As gods of Hindu temples

Like ever seems a stranger 
He's man of old days

A memento of original beauty

In his space awakens

Innocent memories

Like a childish scent

He's like a happy folk song

Full of rage and nudity

Loves the life

The earth

The sorrows of humane

Pure sadness

From depths of his heart

He loves purely

A garden alley

A tree

A cup of ice

A hanger of clothes

My love is a naïve

A naïve man I have hid

In ominous land of strangeness

Between my breasts

As the last sign of a wonderful religion

(Mehr Talab, Hiding love in Heart, 2009).

Referring to the word violence could indicate Forough's attention to beloved's dominance. She tended to choose a beloved to make it easier for her to be in society all by herself. According to the choice, he got to be categorized in third group mentioned by Horney. Avoiding people with the company of an allied beloved. This also referred to love thirst in Forough.

She imagined her beloved as a god in a Nepal temple; an isolated god, a domineering one belonging to ancient times. She deliberately referred to his ancient origin because to her, the current society could not be the one that fulfilled her ideals and the features she demanded. This society had bothered her and caused her great difficulties. As a result, she has chosen a domineering beloved with whom she could avoid people instead of choosing isolation.

Maybe self-sufficiency could also be seen in the mentioned material. Forough did not want and was not able to choose isolation in this period of time but fell in love with a beloved resembling 
herself coming from an ancient past having the appropriate originality in Forough's point of view. Finally, one could be isolated and self-sufficient only by having such beloved.

In the chosen poetry, domineering beloved from Frough has been observed. Someone that could take the responsibility of her grief. But the very same beloved could easily abandon Frouogh's evasive character and caused her another grief by the society.

We could also refer to this topic that there were reasons why women wrote feminine poetry and men wrote masculine poetry. The content of a feminine poem, the rhythm, details, events, tensions, structures, or any tool to visualize and dramatize used by women could be different from men. Forough used feminine characteristics to emphasize her grief of being a second sex and she reflected it in her poetry either intentionally or unintentionally.

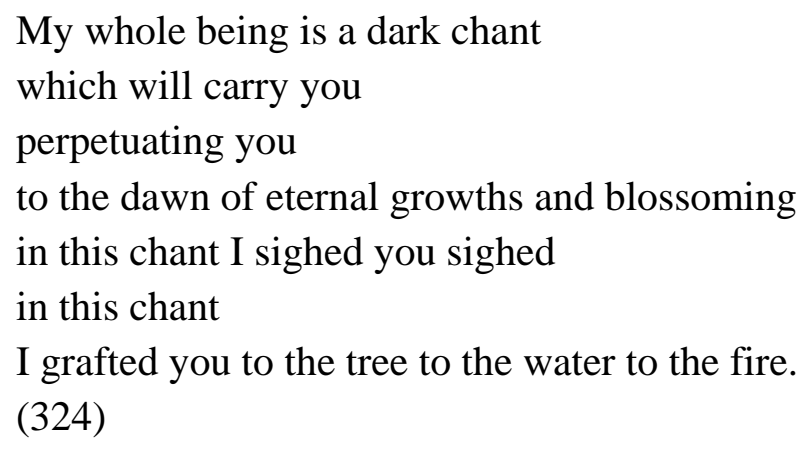

In a room as big as loneliness

my heart

which is as big as love

looks at the simple pretexts of its happiness

at the beautiful decay of flowers in the vase

at the sapling you planted in our garden

and the song of canaries

which sing to the size of a window.

One of the points that Horney referred to was limiting the situation of life. In fact, Forough was trying to keep the current situation and avoiding any kind of changes or hobbies. The major feature of such need was full content. This fact could also categorize Forough in another group developed by Horney: avoiding people.

When I feel someone's lips

I wish they were his

Wish these kissing lips 
Were burning lips of that wicked

When I'm caressed with love

Ask for his bosom

Where to that burning fire gone

Burning in his silence

(60)

In these lines, Forough referred to the wickedness of the beloved. According to Horney's theory, she has chosen the domineering beloved. Horney believed such characters were terribly scared of being abandoned and staying alone. Forough also tried to replace the wicked beloved after being abandoned so this character was scared of being alone.

As we referred to Horney, some people became submissive to others and protected themselves from frustration. The important point was that the poet tried to substitute the beloved as physically but in fact was evading the people in society. In her thoughts, she did not approve of anyone to replace the ancient beloved. In some other poetry by Forough we were dealing with selfsufficiency. When the poet was in better terms with the beloved, she felt completely self-sufficient did not tend to have connections of any type with the society. Here we referred to some evidence of self-sufficiency and love-thirst:

Tell him, Shut behind the doors

I parted from every one If asked ever, I won't fear

I shout that I am in love (61)

When the night falls, and moon hides from sight

I wait in fear

May my gone love come

Seeing a shadow on paths

I'll ran to see

Passing as a ghost it was

I'll stare on other paths behind

In the presented evidence we observed that Forough has become submissive in order to get rid of frustration and was led to people _the beloved of course_but the closed doors and windows 
indicated that Forough was only and exclusively asking her beloved for affection. Forough was not trying to have everyone love her, so according to Horney's categories, she was not the type of moving toward people. However, she was in search of a pure and genuine beloved while she did not consider the society worthy, so she preferred to be silent. To closed the doors and chose isolation reminded the compensation mechanism of Adler. In the society which has taught Forough the state of being the second sex, she has selected solitude and isolation as a coverage to compensate for failures and lived in loneliness with grieves, paradoxes, concerns and feminine expectations.

\author{
Every night in my bed \\ My soul searches for my lost one \\ With these barren efforts \\ The puzzled mind of mine speaks: \\ "You pathetic wretched woman \\ Forget for moments \\ This was a mistake to let him in \\ That wicked lover. \\ The one you're seeking \\ Not thinking of you \\ Stop cry and wreathe \\ Stop! He's with another lover." \\ (Womanhood, 65)
}

We could also refer to the fact that words with high frequency and great details; love; death; loneliness and fear; theatre; expectation; dream; regrets; and sigh were usually used in a feminine narrative which were also seen in Forough poetry as well. In fact, these words were used in order to complete this eastern feminine view. The abandoned Forough was love-thirsty and put all her poetry in hands of feminine narrative. A narration which indicated the wicked beloved of the poet has been a domineering one and her expectations for him to return showed her feeble character that was trying to pass the negative feelings and got her social madness alleviated.

In these lines, dealing with a delicate, fragile, and feminine character describing her expectance is considered. Forough as a love-thirsty character, but the type that did not demand love from everyone or even a certain group. Frough only asked for the love of her beloved. She was sometimes disappointed for love in some moments of life and she demanded her man to 
provide this affection. Forough was not in the category of people who according to Adler tended to hide their imperfections, but she fairly expressed her inabilities in some emotional matters and in the end has limited her life by choosing a domineering partner so she was moving toward separation from people.

We mentioned earlier that in feminine narration we deal with regrets. Regrets and sigh accompany human beings. Humans were always in regrets during their lives. In regret for a past, in regret for a life passing with high speed to become a memory, although memories were an inevitable part of the life. Also, Forough felt melancholy for the things which were crushed as the world moved ahead. There was vague wistfulness in her poetry:

He won't feel my lovely essence

When I'm caressing him

Oh, my dear mirror, I'm dying from regret and awe

As he represses my body

(Mehrtalab: 68) ${ }^{\mathrm{b}}$

Forough investigated the matter of self-sufficiency in all the poems she has written about the contrasts between men and women. She declared this self-sufficiency must be made women avoid men or make them act against them. There were also signs of aggression in her poetry as if she has written these lines in times of great pain and nervous violence. Horney referred to this feeling by declaring the fact that a nervous person felt weakness, inability, feebleness, and severe fear.

The other point that should be considered was that language has always been an equipment to showed not only one's demands, pains, and all the spiritual and inner requests of humans, but also speech style in different personalities. The language formed our understanding of the universe surrounding us that language transfer our thinking in to social life. There were linguistic differences in how men and women used the language. Most of the scientists believed that there were phonic and vocabulary difference between men and women. There were even differences among men related to language (Nemati, 2005:74-75).

bUsing feminine quality to attract the beloved's attention, other's approval, need for affection, love-thirst 
In Forough poetry, the feminine language to express grief and melancholy of women was identified. A harsh language which indicated the existence of a chaotic soul, a feminine soul harassed by men of the society and now it hasn’t found a better way than poetry to displayed her feminine melancholy and sigh.

Oh, you full-hearted woman

Never expect fidelity of men, never

He knows not a word of love

Never tell him your heart's secrets

(73)

We could see the submissive aspect of Forough's character in her avoidance of the society while she was dealing with her beloved and we found her feminine language in this calmness. This indicated that Forough was sometimes moving toward people and society in her poetry and maybe she was trying to find trust:

In those moments of happiness

Can't see any sign of evasion in me

As children do, can't see my silent look

Battling with shame (89)

Obviously, women were emotional creatures and full of feelings. They thought and talked with their six senses. Feelings were directly connected to repetition. They repeated the same meaning in different sentence structures. The talkative quality in women also stemmed from their being emotional (NekZarlaki, 2003). It was people’s firm conviction that "associating rationality and concreteness with masculinity and associating emotionality and imagination with feminine quality was just mere repetition of the most insolent stereotypes of sexism” (Taheri, 2009, p. 96). Women showed interest in emotional connections. They learned sensitivity and subtlety from young age and they possessed a wider range of vocabulary to describe their feelings and also beauty. For example, they could describe a color like red with more details and also women exaggerated while describing their feelings.

As we observed, Forough described her feelings exaggeratedly and tried to be specific; all of her poetry represented a feminine narrative using a language of emotions and fancy. She tried to be as vocal as a man in expressing her romantic feelings. Obviously, there was no need to ignore 
or hide the reality. Canonical or non-cononical, legal or illegal, right or wrong this was the male sex who almost always been in center of attention and in this unfair fight the female has always or almost always gained the second position (Hossein zadeh, 2004).

Most of Forough poetry revolved around expression of pain and solved complexes with a social insight. "there were a lot of pains that agitate her calmness and they were based on fear; fear of self, fear of others, fear of being crushed, ignored, and fear of time and erosion of soul. She has reacted to these crisis and inequality and her art visualize the masculine society and unsaid words of Iranian women who were not heard. She managed to create the narration in her poetry and defeated the inequities and make the sound of the independent women be heard by everyone:

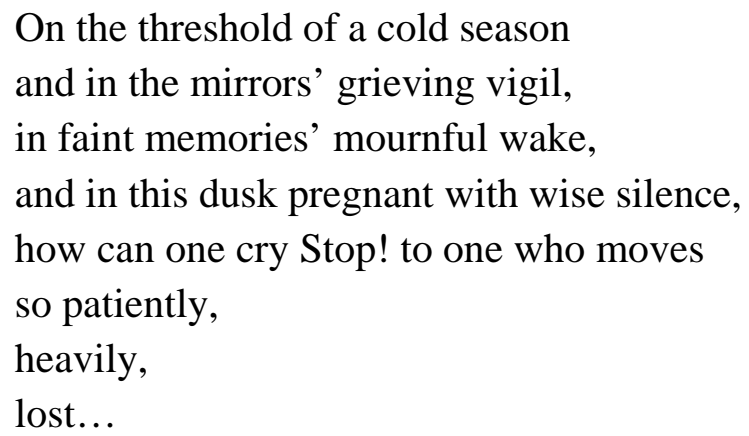

How can one say to this man that he is not alive? that he has never been? $(332,333)$

We could see the feminine language of Forough in these lines again. It visualized the cold in the society replete with masculinity opposed by men, mirrors were mourning and the society was in melancholy. The dawn has learnt to be reticent and her beloved was moving patiently. Foruogh was still in self-sufficiency mood and avoided the society in these lines.

In most of her poetry, we could see the image of limitations and loneliness of the Iranian woman. The biggest pain which elicited the cry of chaos is the weight of tradition chains that trap a naïve girl and transfers her possession to another man, or an unsupported woman who was abandoned and ends in a tragic and bitter destiny, which was a fruitless strict matrimony. Forough was the type who preferred avoiding people. She used the compensation mechanism as below: to avoid and run away from the society and suggesting this method to Iranian women.

Why you have to run?

Why you are in rush? 
To whom you're seeking shelter

In a night as dark as tonight?

(197)

No light glimmering in the wilderness

What's in sight from that far

Those glimmering lights burning there

May be the eyes of wild wolves.

Any genuine poet took side in social tensions because of the hatred they felt for injustice, and the love they had for goodness and purity. So, they used their gift to come to welfare, calmness, and policy. Policy and power had natural consequences that was the chaos in society. These consequences bothered the emotional and committed poets and made them react. Reaction appropriate for different actions. A poet rebelled, some people protested and wrote about it and liked a mirror present a critical realism. Some kept silent and this was how they protested. Forough Farokhzad criticized realistically like a mirror.

We are grown on a wasted land

We rain on a wasted land

We seen nothing in our path

Ridden on the flying horse of his

He passed like a king

(244)

Alas, we are happy and calm

Alas, we are missing and shut

We are happy, as we love

We are missing, as love is cursed.

(244)

Negative attitude to love was obviously seen in these lines due to failure in love. Forough had a domineering beloved and has grown up in a masculine society thus she could not put up with these social issues and complained about them. As we mentioned earlier, Horney defined basic anxiety as an increasing feeling of loneliness and frustration in a cruel world. We could say that her anxiety was the basic feeling from which the other neurotic diseases were born and was closely attached to enmity. 


\section{Conclusion}

In supplied theories, the importance of past was emphasized than future. The family and the society in which a child grew up is really significant. It was clear that living in a situation similar to that of Forough's the second sex would result in having inferiorities. Important thing was that tense environment and her failure in early ages and not being supported created a situation that increased her inferiority. Isolation could be seen and felt in all of her demands for love because isolation was her ultimate preference as her mind has surrendered to pessimism and all her life is full of doubt and fear.

Alfred Adler and Karen Horney theories shared the same nature; inferiority feeling could result in morbid behavior. In Forough poetry, we figured out she has endured a lot of difficulties. She even doubted God and started to rule instead of God. Inferiority feeling was created by partner and also not having a child and it developed in society by being called the second sex. These created paradox in her. Paradox which caused her to be love thirst at times and be elusive at other times and chose various mechanisms in different situations. Isolation and being away from society were preferred. The situation would end in a positive point at the end and she developed like a butterfly. A butterfly moved towards people with love and without pessimism and this indicated her power.

\section{References}

Azin, H. (2004). Idealistic Woman and Deceiving Woman. Ghatreh Publication. (In persian) http://www.nashreghatreh.com/

Barzegar, E. (2009). Psychological Politics. Tehran, SAMT pub. (In persian) http://shadan.ir/

Farrokhzad, F. (2004). Collection of Poems .Tehran, Shadan Publication, $1^{\text {st }}$ Printing. (In persian) http://shadan.ir/

Farrokhzad, P. (2002). Catalogue of Iranian Effective Women (From Past to Present). Tehran, Ghatreh Publication, $1^{\text {st }}$ Printing. (In persian) http://www.nashreghatreh.com/

Farrokhzad, P. (2008). Someone like No One. Tehran, Karvan Publication, $5^{\text {th }}$ Printing. (In persian) https://www.manoketab.com

Freud, S. (1953). Headlines of Psychoanalysis. Translated by Hossein Payandeh. $3^{\text {rd }}$ Printing, Ghtareh Publication. (In persian) http://www.nashreghatreh.com/ 
Ghibadi, H. A., Houshangi, M. (2009). Psychological Critics and Analysis of Zaal Character from Alfered Adler Point of View. Literary Criticism Quarterly, 2(7), 90-119. (In persian) http://ensani.ir/file/download/article/20120828100741-1184-14.pdf

Landin, R. W. (1999). Theories and Structures of Psychology. Translated by Yahya Seyed Mohammadi, $1^{\text {st }}$ Printing, Tehran, Virayesh Publication. (In persian) https://ravabook.ir/

Moghadasi, A., Chakali, B. (2018). Reasons of Forming Syllable in Bashar Ibn Burd. Literary Arab Publication, New Edition, Tehran University, 1, 62-64. (In persian) https://press.ut.ac.ir/

Moradi, S. (2005). Bibliography of Forough Farrokhzad. Ghtareh Publication, $2^{\text {nd }}$ Printing. (In persian) http://www.nashreghatreh.com/

Nemati, A. (2005). Analysis on Language Differences of Men and Women; Study on Sociology of Language. Humanities Department of Semnan, 5. (In persian) http://ensani.ir/file/download/article/20101113181939-23.pdf

Nersisians, E. (2004). Anthropology of Gender. Tehran, Afkar Publication. (In persian) https://www.iranketab.ir/publisher

Shakeri, J. (2018). Psychological Analysis on Characters of Three Stories of Geda, Khakestar neshin, and Asghaldooni by Gholamhossein Saedi based on Karen Horney Theory. Literary Survey Text, 19(63), 67-88. (In persian) http://ltr.atu.ac.ir/article_1398.html

Shamisa, S. (2009). Kinds of Literature. $10^{\text {th }}$ Printing ( $3^{\text {rd }}$ Edition), Tehran: Ferdows Publication. (Inpersian) https://ferdosbook.com/

Shamloo, S. (2019). Shools and Theories in Psycholoy of Personality. $9^{\text {th }}$ edition, Tehran, Roshd Publication. (In persian) http://www.roshdpress.ir/

Shultz, D., Allen, S. (2015). Theories on Personalities. Translated by Yahya Seyed Mohammadi, TeHran, Virayesh Publication. (In persian) https://ravabook.ir/

Shultz, D., Allen, S. (2015). Theories on Personalities. Translated by Yahya Seyed Mohammadi, TeHran, Virayesh Publication. (In persian) https://ravabook.ir/

Shultz, D., \& Allen, S. (2017). Theories on Personalities, Translated by Yahya Seyed Mohammadi, TeHran, Virayesh Publication. (In persian) https://ravabook.ir/

Siasi, Ali Akbar. (1991). Theories on Personalities. Tehran, Tehran University Publication. (In persian) https://press.ut.ac.ir/ 
Taheri, G. (2018). Women Dialogue and Writing: Reality or Illusion. Language and Literature new edition, Publication of Allameh Ghazvin University, Iran. (In persian) http://www.allamehghazvini.ac.ir/

Taheri, M. (2010). Pychological Politics of Mohammad Reza Pahlavi Based on Karen Horney Theories. Research Center of Humanities and Cultural Studies, 1(2), 65-85. (In persian) http://politicalstudy.ihcs.ac.ir/article_149.html

Yousefi, S. (2007). Studying Poem and Life of Forough Farrokhzad. Tehran, Afarinesh Publication, $2^{\text {nd }}$ Printing. (In persian) https://www.chaponashr.ir/AFARINESHH

Zarlaki, S. (2003). Women against Women; Psychological Survey on Alba de Cespedes Works. Tehran, Farhang Kavosh Pub. (In persian) http://chaponashr.ir/farhangekavosh

Zarrinkoub, A. (2017). Literary Criticism. Tehran, new edition, Amirkabir Publication. (In persian) http://amirkabirpub.ir/ 